\title{
Image of President Asif Ali Zardari as Portrayed by Daily Dawn and News: A Discourse Analysis of Editorials
}

Muhammad Riaz Raza* and Muhammad Wasim Akbar

Department of Mass Communication, City Campus, Gomal University D.I. Khan, KPK, Pakistan

\begin{abstract}
The main objective of this research study is to investigate as to how the image of President Zardari is being presented in the print media discourses. The media in Pakistan is enjoying a free environment after a long martial law of President musharraf. The Jang group is a leading group having media outlets in the field of print as well as in electronic. The Jang group, in general, has a biased perception and involved in an anti government media campaign since the government took over in 2008. Since the Pakistani media has been enjoying a powerful status as a main stake holder to make or to topple down any government. Pressure groups mend and mould the media agenda if it is contrary to their news agenda through some media groups. Further this study should be analyzed in the context of the interests of some big powers which influence and shape news agenda of poor countries and specially after 9/11 there has been a paradigm shift in the world's media. In this context the media coverage in Pakistan shows that the President Zardari has portrayed negatively in most of the print media outlets of Jang group. Most of the editorials in leading newspapers portrayed President Zardari as corrupt, untrustworthy, disloyal, criminal and dishonest by undermining his political status and political achievements. This paper discusses the difference of portrayal of his image in two leading English language newspapers of different groups - The News and Dawn. The News belongs to Jang group while The Dawn owned by Herald publications Ltd. The researcher explores the trend by using framing and priming theories. Editorials of these two Pakistani newspapers published from Nov, 2009 to Jan 2010 were selected. Altogether, 180 editorials were read out from these two newspapers, 37 editorials from The News and 26 editorials from The Dawn were found relevant to the issue of NRO with special reference to Mr. Zardari. The paper concludes that The News constructs a biased and negative image of President Zardari by its speculative language, tone and representation while writing on NRO in the editorial discourses Dawn reflects the same issue in neutral and balanced way.
\end{abstract}

\section{Significance}

Pressure groups have been much significant in Pakistan's media history as there were a number of example when elected governments were topple down and then dictators legitimized their governments with the help of Media and Judiciary. International players particularly the US dictate and use these pressure groups to protect their vested interests in the region through the dominance in the field of media as they have the means and ability for setting the agenda of global communication. The paper attempts to highlight the partial approach of Daily The News as an organization. The editorial is the official opinion of the newspaper. The Dawn's approach has been neutral and objective in most of its editorials. It is also pertinent to mention here that Jang group has cross media ownership having private news channels like Geo news, Geo Super etc. It is interesting to note that there has been the same policy of opposing government as an institution in its print and broadcast media outlets. The study should be seen in the context of the interests of the big powers who use the local conglomerate media to build public opinion.

\section{Introduction and Background}

During the last couple of years, media in Pakistan widely covered the issue of National Reconciliation Ordinance (NRO), its beneficiaries and legalities. This ordinance was passed in the last part of Musharraf's regime in 2007 to regularize and accommodate the cases of corruption made during democratic regimes 1988-1998 against Miss Benazir Bhutto (Late), President Zardari and thousands of others including bureaucracy and military establishment. A number of members of Muslim League (Q) and Muslim League (N) were also in the list of beneficiaries of the NRO. The immense world pressure and continuous struggle of Miss BB (Late) forced President Musharraf to allow the big political parties to participate in the political process. The main hurdle in the way of PPP leaders was those corruption cases which initiated by Nawaz government while he was in power. It is interesting to mention here that not a single case against Mr. Zardari has been proved despite of his 8 years imprisonment. The main purpose of this ordinance was to bring back the political leadership (BB and Nawaz brothers) to take part in the coming elections of 2008. Therefore, Musharraf passed NRO ordinance in 2007 through which these leaders came back in 2007-08. The list of NRO beneficiaries shows that politicians were 34 out of 8041 beneficiaries including bureaucracy, military establishment, business community and government officials.

After the long mini martial law of President Musharraf, some glimpses of democracy are being seen after the general election 2008, the most transparent according to the international analysts. Political parties, once again, are trying to deepen their roots with the help of, comparatively, a free press. Although recent rapid developments in media systems are progressive in nature but still it is lacking in objectivity. Pakistani media is a bit good pace since 2000 when a number of private news channels were brought into notice. At the same time,

*Corresponding author: Muhammad Riaz Raza, PhD Scholar, Department of Mass Communication, City Campus, Gomal University D.I. Khan, KPK Pakistan, Tel: 0092-301-5298740; E-mail: rayyaz31@hotmail.com

Received December 17, 2011; Accepted March 26, 2012; Published March 28 2012

Citation: Raza MR, Akbar MW (2012) Image of President Asif Ali Zardari as Portrayed by Daily Dawn and News: A Discourse Analysis of Editorials. J Mass Communicat Journalism 2:113. doi:10.4172/2165-7912.1000113

Copyright: (C) 2012 Raza MR, et al. This is an open-access article distributed under the terms of the Creative Commons Attribution License, which permits unrestricted use, distribution, and reproduction in any medium, provided the original author and source are credited. 
the 'freedom of press' can be seen under the shadow of some hidden forces which have their own agenda and they direct media whenever they need to safeguard their vested interests. Lack of professionalism and system approach by some media institutions has already given irreparable loss to media institutions and democracy. It seems on the whole that media players are trying to play its role by keeping the momentum of quality of information intact among print media outlets. The media is struggling in this part of the world for bringing some positive attitudinal change among people on role of democracy and the responsibilities in relatively an independent and free environment. We know to report, to make and to present an event into news is not a simple process and it needs fairness and objectivity in all its stages. Our print media history spreads over 63 years with number of ups and down under the dark shadow of military and semi democratic rule which gave vulnerable loss to the growth and independence of media in Pakistan. In the race of commercialization, the conglomerate media is forgotten the core objectives and responsibilities of the media; to provide in time and accurate information and to gratify the target audiences according to its social and cultural needs. Opinions based on biased information are not always the same as opinions based on neutral information because the effects of the biased information may lead to the viewer / reader in a chaos rather than their gratification. In the light of above background information, this research paper tries to find as how Pakistani print media, Daily Dawn and The News portrayed the image of President Zardari in their discourses.

After literature review, the following research questions have been developed to get the objectives of the study:

1. Is the coverage in Pakistani print media discourses mainly criticizing the President or appreciating?

2. Is the policy of print media focused only on constructing a bad image using predominantly negative portrayals?

\section{Literature Review}

Frame analysis is a type of discourse analysis that asks, what activity are speakers engaged in when they say this? What do they think they are doing by talking in this way at this time? [1]. To frame is to select some aspects of a perceived reality and make them more salient in a communicating text, in such a way as to promote a particular problem definition, causal interpretation, moral evaluation, and/or/treatment recommendation for the item described [2]. Karen (2005) [3] cited Tankard, Hendrickson, Silberman, Bliss, \& Ghanem (1991) that "a frame is a central organizing idea for news content that supplies a context and suggests what the issue is through the use of selection, emphasis, exclusion and elaboration". We can see how a priority is given to an issue to achieve specific goals set by the journalist. Repetition, consistency, exclusion, inclusion and partial commentary on the issue helps in moulding the opinions in the desired directions through framing techniques. The presentation style of an issue, like 'story line' which does support in giving the meaning to the story in a particular direction. Gadi [4] and Gitlin [5] cited, 'that largely unspoken and unacknowledged and organizes the world both for journalists who report it and, in some degree, for us who rely on their reports'.

Modern media's spin doctors are called experts who often create fake controversies and give favourite angles to the stories whenever they want to do so. Speculative, idiomatic, chaotic, lured, storytelling language are some techniques of modern framing. The public opinion can be changed and turn against you in no time as the technique of framing has strong effects on the audiences. The policy of highlighting negatives and hiding positives of an issue / individual can change opinion of the audiences as and when media desires to do so. We have seen a sharp growth in recent years a trend to write on discourse analysis as a persuasive technique. In this part of globe, this practice is revolves around political issues and political leaders due to the openings of new horizons in the field of communication.

Shaista and Zafar [6] cited Mac Lure that "discourse analysis method is used to analyze discourses on a particular issue both conscious and unconscious agendas of the writer". According to Hall, 'meaning can never be fixed'. People have 'conceptual maps' that organize and assign meaning to events. Meaning is expressed through language and representation. 'Meaning needs a discourse to make it meaningful...without language there is no representation, no meaning'. Actually 'media frame' sets a tone for particular story which helps to mould the opinion of the audiences. Media frames as, 'largely unspoken and unacknowledged, organize the world both for journalists who report it and, in some important degree, for us to rely on their reports'. Meyers and Davis $[7,8]$ suggests that 'discourse is not simply a linguistic practice; it refers to and constructs knowledge about a particular topic'. 'Selecting and highlighting some facets of events or issues and making connections among them so as to promote a particular interpretation, evaluation, and or solution" [9]. As we notice that some sections of media love to highlight one aspect or angle and to hide the other at the same time about the issue. Moreover, it follows an explanation, evaluation and commentary to get the desired goals set by media organization / journalist.

The very common phenomena in today's journalistic activities are the frequent use of speculative language. According to Lindsay (2003), 'speculative language is a form of subjective speech and as such its presence in press content defies the journalist principle of objectivity'. Pakistani media have the tendency to use speculative language to catch the maximum audiences. They love to pass comments and opinionated news to their audiences by sidelining objectivity the sole purpose of journalism. The present study explores the phenomena of partisan journalism which are being rooted in our media activities to get commercial gains or otherwise.

\section{Hypotheses}

H1: The News depicts the image of President Asif Ali Zardari negatively whereas Dawn does this in a neutral way.

H2: The News represents President Zardari with relatively more biased image than Dawn.

\section{Dawn and The News}

The Dawn is widely circulated English newspaper which has a quite balance in its policy. It was the first English newspaper that was founded by Mr. MA Jinnah the founder of Pakistan. Target of the paper are those segments of the society which are highly educated and decision makers. Muhammad Ali Jinnah says about Dawn in the these words: "The Dawn will mirror faithfully the views of India's Muslims and the All India Muslim League in all its activities: economic, educational and social and more particularly political, throughout the country fearlessly and independently and while its policy will be, no doubt, mainly to advocate and champion the cause of the Muslims and the policy and programme of the All India Muslim League, it will not neglect the cause and welfare of the peoples of this sub-continent generally". The weekly circulation of newspaper is about 138,000 copies in major cities of the country. By contrast to the Dawn, the News is a progressive, radical 
and open in its entire business. Both the newspapers fulfill the needs of different quarters of the society. Daily News has circulation of about 140,000 copies. The newspaper is published from Karachi, Lahore and Rawalpindi/Islamabad. The News is enjoying wide readership in the country. The newspaper is considered to be an aggressive in nature as compare to the Dawn.

\section{Method}

The method adopted in this study to explore the discourses of President Zardari's image in these two leading newspapers. The qualitative method has been selected to analyze the construction of image of President Asif Ali Zardari in these discourses. The study focuses on the coverage pattern of two leading newspapers on NRO with special reference to President Zardari. The editorials of the two English newspapers - The News and Dawn, published between Nov 2009 to Jan 31, 2010 were chosen to identify the frames of the image of President Asif Ali Zardai. This period was considered to be the prime time of the issue, particularly when debate over NRO issue was taking significant space in all print media outlets. Altogether, 63 editorials were published from both the newspapers on NRO. 37 editorials in The News and 26 editorials in Dawn were published on NRO issue. The main focus of this research study was the critical review of issue of NRO in editorials which was used to sketch the image of President Zardari. The language, tone, consistency and representation of the editorials published in The News were criticizing NRO and constructing a negative image of President Zardari prominently while The Dawn portrayed the image of president Zardari neutrally by balanced projection. The News projected NRO as conflict-oriented while Dawn covered the issue as system specific. Some metaphors were also used by The News to draw a muddy picture of the President. In number of editorials the language and representation of The News was remained speculative which leaves the issue more chaotic, uncertain and subjective.

\section{The News states that:}

The Zardari presidency is clearly crumbling before our eyes and the president has little chance of avoiding this disaster, which is of his own making. Domestically he has lost the support of the media with but a few diehard exceptions. He has scant support by the military and is being harried by an effective opposition. At the grassroots his popularity is at rock-bottom. Internationally, the US is said to be fearful of presidential 'collapse' and he is under intense pressure to scrap the 17th Amendment and restore the powers of both prime minister and parliament (i).

The Newspaper observations were based on speculations which have not any concrete evidence and scholars are of the view that speculative language or speculations of future events is called a subjective approach. Newspaper discusses the 'disaster' to come, the presidential collapse, losing media support domestically as well as internationally but it never gives any concrete or solid proof or source of all such things which are going to be happened. The paper further says that President has lost the support of military establishment. The tone and style is aggressive and criticizing towards presidency which smells biasness on the part of a media organization. A chaotic situation has been created by the daily News by using lured language. A number of weaknesses of the presidency have been discussed to build public opinion on the issue of NRO and president - part and parcel. Again negative image of the president Zardari has been portrayed by The News in its editorials.

\section{The newspaper further says that:}

While Mr. Zardari has been drawing much of the flak for the paralysis we see in government, and indeed he has been partially responsible for this by intervening in decision-making at every level, the cabinet must accept a significant chunk of responsibility for failing to get things moving in any meaningful direction (ii).

Here, it replicates the same tone of criticism by using stereotypical frames for President Zardari. The News of the view that Mr. Zardari is partially responsible for the crises and it is assumed that he is intervening in Prime Ministers affairs. Obviously, it constructed the negative image of President when The News expresses its worries over political, economic and social life of the people by framing Mr. Zardari as partially responsible. The commentary is vague, speculative and ambiguous in terms of language tone and representation.

\section{The News further describes that:}

Constitutionally, some lawyers had argued, no criminal case could be instituted against the president, but today he must be looking over his shoulder and eyeing his foreign investment portfolio - not to mention future options as a place of domicile (iii).

The newspaper has just speculated the things by using idiomatic and lured language to develop a negative image. The newspaper exaggerates the things based on speculations. The tone is also negative which craft a negative image of the president.

\section{The newspaper opined that:}

Largely as a result of grave errors in judgment and leadership style, the presidency is increasingly isolated. The PM is well aware of this and his latest speech to the National Assembly represents an effort to avoid being seen as a part of the presidential camp (iv).

The minor difference of opinion has been projected as a division between PM and president by priming, exaggerating and distorting the things. The newspaper tried to draw a line between Mr. Zardari and Mr. Gilani camp by undermining their each others understanding on the national and international issues. The language is speculative and negative and such words and phrases are deliberately used which helps in distorting the image of President.

The News says that 'The terrorists and their ideological masters who do not mince words in claiming that they will soon rule this country in their own warped way will be the only beneficiaries of this mass political suicide by parliament and politicians; and this is what it will be if the passing of the NRO comes about (v).

The News depicted the grim picture of the coming days for President Zardari and its created hype and chaos about any fake political crises by saying that terrorists will soon rule this country. There is no concrete evidence in supporting the stance as the speculative and aggressive words have been used. The issue of NRO has been exaggerated and presented out of proportion.

It further says that 'it seems that by distancing himself from the presidency and continuing his efforts to court the PML-N, Mr. Gilani hopes to survive even if the presidential ship sinks' (vi) In another editorial the newspaper says that 'The president is not going to go quietly and he will fight to retain what he can of his power and position, but the die is now cast - it is a matter of 'when' and not 'if' (vii). The newspaper predicts the quitting of president but not quietly and in its opinion the die is the cost. As we understand media has immense potential to 
mould the opinions by highlighting, priming and out of proportion to any issue they wish to. The News criticized only Mr. Zardari leaving all of 8040 (expected NRO beneficiaries) and gave undue hype to the issue by presenting President as the source of problems.

The News considers president Zardari a threat to the democratic and social system of the country due to allegations of corruption without any proof. Most of the editorials of News describing a grave political unrest and there will be a great loss to the country's judicial system if NRO remains intact. The newspaper never discussed the role of parliament and its discretion to pass NRO bill but it discussed demerits and excludes merits. The paper emphasized that this law will be harmful for the judicial system. Some editorials of The News highlighted NRO as a conflict between Judiciary and President. The language and theme of the editorials were significant in depicting the negative picture of the president Zardari.

Dawn critically examines issue of NRO in the national and broader context and avoid to target and highlight it in a subjective way. The approach is clearly neutral and impartial. While making discourses on president the approach has been remained objective and system specific. The details of some editorials of Dawn discussed about the $\mathrm{NRO}$ and President Zardari is given in the following:

The Dawn, 01 Nov, 2009, Islamabad-Pakistan

The Dawn, 08 Nov, 2009, Islamabad-Pakistan

The Dawn, 03 November 2009, Islamabad-Pakistan

The Dawn, 05 Nov, 2009, Islamabad-Pakistan

The Dawn, 14 Nov, 2009, Islamabad-Pakistan

The Dawn, 07 December, 2009, Islamabad-Pakistan

The Dawn, 13 December, 2009, Islamabad-Pakistan

The Dawn, 17 December, 2009, Islamabad-Pakistan

The Dawn, 20 December, 2009, Islamabad-Pakistan

The Dawn, 23 December, 2009, Islamabad-Pakistan

The Dawn, 27 December, 2009, Islamabad-Pakistan

The Dawn, 18 January, 2010, Islamabad-Pakistan

The Dawn, 27 January, 2010, Islamabad-Pakistan

The Dawn, 30 January, 2010, Islamabad-Pakistan

The differentiation on stuff of both the newspapers can clearly be observed on the issue of NRO. The dawn portrays the issue in the following lines:-

AS the drumbeat of criticism of the government, and particularly the person and leadership of President Zardari, grows louder at home and abroad, the PPP used the meeting of its central executive committee on Monday to repose its confidence in the leadership of Mr Zardari and in the government at the centre generally (viii)

H2: The News represents President Zardari with relatively more biased image than Dawn.

The News criticised NRO and President Zardari in most of their discourses in a biased way while Dawn projected NRO and president Zardari in a neutral way. Journalistic language has been avoided in Daily The News. The News says that:
The president obviously fears the consequences of an NRO-free environment, which would make it possible for corruption cases against him to be revived. The courts would then need to decide if the presidential immunity which protects apparent even now that as the president' continues his efforts to parry the blade, he is suffering more and more wounds with each day that passes (ix). It is clear after reading out the editorials of both the newspapers that President Zardari's portrayal with negative images is more prominent in The News than Dawn. The News opined that:

The president has been badly wounded by the NRO debacle. While the impeachment threat that has now begun to hover following new charges of corruption could finally persuade the president to call it a day, for the moment he seems determined to cling on $(\mathrm{x})$.

The News warns president will have to face impeachment and new allegations of corruption. It looks from the given text of the newspaper that writer of the editorial is opinionated and tone is negative, directive and subjective. The conscious bias is more visible than objective bias.

The Newspaper further describes that "To say that Mr Zardari is the wrong man in the wrong job at the wrong time understates the case by several orders of magnitude" (xi).

The language, tone and representation is partial and targeted as the culture of passing judgement at media's end is being strengthened.

In another editorial The News of the view that "There is conjecture that the NRO cases may yet have an impact on the top beneficiary of the controversial law - a certain Mr Asif Ali Zardari"(xii). As we read out editorials of The News we observe much of the focus is on corruption in political camps while the list of NRO beneficiaries shows that politicians are 34 out of 8041 beneficiaries including bureaucracy and military establishment but the newspaper primed only politicians and particularly president Zardari as the main beneficiary and the root cause. The Newspaper tried to build opinion of the public that top beneficiary of this law will be the president Zardari and it is clearly showing the subjective approach. The newspaper further criticized presidency and president in these words that:

With the NRO scandal the issue of corruption has been focused on in depth. But while all eyes have been directed in one place - that palatial presidency on the hill - occupied by a man widely perceived as corrupt, the fact is that corruption is a curse that is far more deeply rooted (xiii).

Again the focus is only on president and newspaper declares the president widely perceived as corrupt and the text has been supported by idiomatic and crispy language. The newspaper describes in the same editorial with a different language when it discusses Chaudhrys of Gujarat using beneficiaries instead corruption. The paper used different frames for different characters to define the same phenomena. "The trend was well-entrenched over the Musharraf government's tenure, with the Chaudhrys in Gujrat emerging as the biggest beneficiaries" (xiv). The News further analyzes that:

A story in this newspaper details massive corruption in the Pakistan Steel Mills. Another discloses a plan to cover it up and allow the top management to get away with looting the organization. Meanwhile, a former naval chief has confirmed that a deal to purchase submarines from France did indeed involve kickbacks for key officials in office at the time. Among them of course was a certain Mr Asif Ali Zardari (xv).

The newspaper could not give any concrete evidence and referred 
the same newspaper which disclosed the plan of corruption in Pakistan Steel Mills. Among the corrupts of course was a certain president Zardari. The newspaper again depicts a negative picture of president without any proof. The newspaper also discusses the issue of kickback in submarines deal---a certain Mr. Asif Ali Zardari without any proof or record. The editorial is discussing president in a biased, partial and negative way. The News also discusses that "today he must be looking over his shoulder and eyeing his foreign investment portfolio - not to mention future options as a place of domicile" (xvi). In preceding lines phrases and idiomatic language to deliver half-truth to the readers was the objective and by doing this newspaper portrayed a muddy and biased image. Mr. Zardari was notorious with the name of 'Mr. 10\%' in the previous government of his slain wife in 1994-1996. This perception of president Zardari had developed during BB's both governments and The News has given salience to this perception and used the stereotypical frames for its desired goals. The News in another editorial says that 'The president now appears a cornered man. As the biggest beneficiary of the blackest ordinance imposed on this country, he faces a plethora of cases' (xvii). Demands are already pouring in that the billions of dollars retained overseas by Zardari be brought home. Many believe he has few options but to resign and vanish, aboard a private plane, into the sunset. Most would wave a glad goodbye' (xviii).

As shown in the preceding lines The News used different phrases in negative connotation than Dawn does. These lines of the editorial emphasize upon the writer's appeal to the emotion of the readers. The News has been used conscious bias than objective bias in the coverage the NRO. The News says that 'According to a report in this newspaper, the vindictive strategy aimed at creating hurdles in the way of the courts has been initiated by the presidency" [xix]. Again the finger has risen to president by associating the story of vindictive strategy without any concrete evidence and arguments. The News painted a picture of President Zardari as a corrupt, criminal and unwanted person for Pakistani people. This might be intentionally or otherwise but the paper attempted to focus President Zardari as a focal point for negative propaganda in all its discourses. The newspaper further stated that 'The political chickens that the PPP hatched are coming home to roost, in a rather hurried manner. The first major crack in the ruling coalition has appeared with the polite but firm advice by MQM chief Altaf Hussain to President Asif Ali Zardari: step down to save the system. The black sheep in our political system must be identified and removed' ( $\mathrm{xx}$ ). Language of the editorial is not objective but subjective and a number of phrases have been used with conscious bias.

We can observe the frequent use of non journalistic and aggressive language in the editorials towards President Zardari like fierce storm, hatched, black law, black sheep, corrupt deeds, henchmen, fatal sword, parry the blade, wounds, salvage, yawning chasm, dirty game of power, NRO debacle, cling on, flounders, ignominy, crumbling, NRO scandal, indefensible law, frightening lack of acumen, absconder, blackest ordinance, belligerence, crippling, thundering, ambit of criminality, Byzantine, 'minus-many operation, Punishing the SC, vindictive strategy, blatantly unjust law, accident-prone, stumbling, , disinfectant smell of accountability etc. All these words have negative connotations. The News remained more active in terms of quantum and regular in projecting NRO and issues related to President Zardari while we noticed that The Dawn cover the issue rather in longer gaps with lesser degree of contents.

Now look some metaphors and examples of biased language which have been used for painting a negative picture of the President like sinking President, scared man, accused of serious crimes, Zardari and his henchmen, lack of honesty, absconder, rock bottom, plethora of cases, wrong man, guilty of crime, SGS corruption etc. The News focused the issue of NRO to portray the negative image in most of its editorials instead to project $\mathrm{NRO}$ as an unconstitutional.

i. The News, 02 December 2009, Islamabad-Pakistan

ii. The News, 08 November 2009, Islamabad-Pakistan

iii. The News, 17 December 2009, Islamabad-Pakistan

iv. The News, 05 November 2009, Islamabad-Pakistan

v. The News, 03 November 2009, Islamabad-Pakistan

vi. The News, 10 November 2009, Islamabad-Pakistan

vii. The News, 02 December 2009, Islamabad-Pakistan

viii. The Dawn, 08 Nov, 2009, Islamabad-Pakistan

ix. The News, 05 November 2009, Islamabad-Pakistan

x. The News, 10 November 2009, Islamabad-Pakistan

xi. The News, 02 December 2009, Islamabad-Pakistan

xii. The News, 25 November 2009, Islamabad-Pakistan

xiii. The News, 05 December 2009, Islamabad-Pakistan

xiv. The News, 05 December 2009, Islamabad-Pakistan

xv. The News, 13 January 2010, Islamabad Pakistan

xvi. The News, 17 December 2009, Islamabad-Pakistan

xvii. The News, 18 December 2009, Islamabad-Pakistan

xviii. The News, 18 December 2009, Islamabad-Pakistan

xix. The News, 16 January 2010, Islamabad-Pakistan

xx. The News, 03 November 2009, Islamabad-Pakistan

\section{Discussion}

It is the matter of newspapers editorial policy that how some particular issue to be framed and what aspects of the issue to be highlighted. It is clear from the study of both the newspapers editorial discourses that they are very much different from each other. One can predict the way through the given metaphors, tone, language representation in the The News clearly constructed negative image of President Zardari. It is also observed that the language of The News is more aggressive than The Dawn. The theme of the editorials demonstrates how The News painted a picture of President Zardari as a corrupt, criminal and unwanted person for Pakistani people. The News used frequently such words that have negative connotation like absconder, sinking president, fierce storm, hatched, black law, black sheep, corrupt deeds, henchmen, fatal sword, parry the blade, wounds, salvage, yawning chasm, dirty game of power, NRO debacle, cling on, flounders, ignominy, crumbling, NRO scandal, indefensible law, frightening lack of acumen, blackest ordinance, belligerence, crippling, , thundering, ambit of criminality, Byzantine, 'minus-many operation, Punishing the SC, vindictive strategy, blatantly unjust law, accidentprone, stumbling, , disinfectant smell of accountability etc. This might be intentionally or otherwise but the paper attempted to focus President Zardari as a focal point for negative propaganda in all its discourses. The tone of these editorials is overall negative and condemning towards 
Citation: Raza MR, Akbar MW (2012) Image of President Asif Ali Zardari as Portrayed by Daily Dawn and News: A Discourse Analysis of Editorials. J Mass Communicat Journalism 2:113. doi:10.4172/2165-7912.1000113

Page 6 of 6

the President. It includes negative, unfavourable, and sometimes non journalistic language has been used. The most prominent aspect of The News is the use of speculative words to support its point of view like if, will, should, could, were, would then etc which contribute an uncertain environment and chaos in a particular scenario which smells subjective bias. The News used aggressive and negative language while The Dawn rarely used such language and remained neutral in most of its discourses. We can see the negative metaphors and negativity in terms of representation and overall theme in The News editorials for Mr. Zardari while Dawn rarely employed such metaphors with negative connotations and rarely used speculative words. It is also observed that The News remained more active in terms of quantum and regular in projecting NRO and issues related to President Zardari while we noticed that The Dawn cover the issue rather in longer gaps with lesser degree of contents. Sometimes the language and style is so harsh and aggressive towards President Zardari. The News covers the issue in a way that NRO phenomena is an umbrella and fulfilling the desires of President leaving thousands of other beneficiaries including top bureaucracy, Army officers, business community and politicians which indicates the angling to the issue. Distortion and exaggeration on the issue by opining the situation rather chaotic and damaging for peace and harmony in the country remained a more focused point for The News. It is clear from the text examined that editorial contents of The News are condemning and biased in its tone and style. The paper makes 'NRO and President Zardari a part and parcel in most of its editorial discourses and tried to build an opinion that only Mr. Zardari is the beneficiary of NRO while Dawn has been projected the same issue as purely a system specific, neutral and objective.

\section{References}

1. Tannen D (1993) Talking Voices: Repetition, Dialogue and imagery in conversational Discourse. Cambridge: Cambridge UP.

2. Entman RM (1993) "Framing: Toward Clarification of a Fractured Paradigm". Journal of Communication 43: 51-58.

3. Karen S (2005) Constructing Political Reality, News Narratives and News Framing. Rowman \& Littlefield Inc Publishers

4. Gadi W (1999) Media and Political Conflict. Cambridge Univesity Press United Kingdom.

5. Gitlin T (1980) The World is watching: Mass Media in Making and unmaking of the New Left.

6. Shaista M, Zafar I (2009) Construction of Taliban Image in Pakistan: Discourse Analysis of Editorials of Dawn and The News.

7. Meyers M (2004) African American women and violence: Gender, race, and class in the news. Critical Studies in Media Communication 21, 95-118. Routledge Taylor \& Francis Group.

8. Davis MJ, French TN (2008) Blaming Victims and Survivors: An Analysis of Post-Katrina Print News Coverage. Southern Communication Journal 73: 243257.

9. Entman RM (2004) Projection of Power, Framing News, Public Opinion \& US Foreign Policy.

10. Bouziane Z (2009) Media Policy in Morocco's Democratic Transition. IAMCR OCS, IAMCR 2011 -Istanbul.

11. Giles DC (2002) Advanced research methods in psychology. London: Routledge

12. Kelly and Pax (2004) Bias in the Media. Think on Journalism.

13. McKinney MS (2005) Communicating politics: Engaging the public in Democratic life. 